\title{
Transgenics in Fruit Crops Research- A Review
}

\author{
V.S.S.V. Prasanna ${ }^{1 *}$, E.K. Naik ${ }^{2}$ and K. Siva Sankar Reddy ${ }^{3}$ \\ ${ }^{1}$ Department of Pomology \& Post Harvest Technology- UBKV-Coochbehar, W.B-736165, India \\ ${ }^{2}$ Department of Fruit Crops, HC \& RI-Periyakulam, TNAU-Coimbatore, India-641001 \\ ${ }^{3}$ Department of Plant Breeding \& Genetics, Assam Agricultural University, \\ Jorhat - 785 013, India \\ *Corresponding author
}

\section{A B S T R A C T}

\section{Keywords}

Biotechnology, Crop improvement, Genetic engineering, Molecular markers, Transgenic

\section{Article Info}

Accepted:

20 November 2018

Available Online:

10 December 2018
Present increasing trend of population is alarming for food shortage. It was estimated that by the year of 2050 the population rate may increase up to 9 billion. Rapid increase of human population together with global climate variability resulted in increased demand of plant based food and energy sources. Conventional breeding is still limited due to genetic restrictions (high heterozygosity and polyploidy), long juvenile periods, selfincompatibility, resources restricted to parental genome and exposed to sexual combination. Thus, there is an urgent need for the biotechnology-assisted crop improvement, which ultimately aimed to obtain novel plant traits. Plant genetic engineering has opened new avenues to modify crops, and provided new solutions to solve specific needs. Therefore, this paper reviews the recent trends in the field of transgenic in fruit crops.

\section{Introduction}

Genetically modified organisms are the one which the genetic material has been altered in such a way to get the required quality. This technology is called as Recombinant DNA technology or Genetic engineering. Genetically engineered organisms are referred to as Transgenic or cisgenic organisms. The process of transferring, integration and expression of transgene in an organism are called transgenic transformation. A transgenic crop plant contains a gene which has been artificially inserted instead of the plant, acquiring them through fertilization or pollination. The inserted gene sequence (known as the transgene) may come from another unrelated plant. Improvement of the plant characteristics by transfer of selected genes into fruit plant cells is possible mainly through two principal methods: Agrobacterium-mediated transformation and micro projectile bombardment. Genetic transformation and genetic engineering contribute to an overall increase in crop productivity. Contrary to conventional plant 
breeding, this technology can integrate foreign DNA into different plant cells to produce transgenic plants with new desirable traits. These biotechnological approaches are a great option to improve fruit genotypes with significant commercial properties such as increased biotic (resistance to disease of virus, fungi, pests and bacteria) or abiotic (temperature, salinity, light, drought) stress tolerances, nutrition, yield and quality (delayed fruit ripening and longer shelf life) and to use as directed to produce proteins, edible vaccines and biodegradable plastics (Khandelwal et al., 2011).

\section{Transgenic fruit crops}

\section{Papaya}

The transgenic papaya has been developed against papaya ring spot virus using coat protein mediated resistant in university of Hawaii by Dennis Gonsalves. The coat protein gene from PRSV was isolated, cloned and used for transforming papaya to provide resistance against the severe strain of the same virus. The target cultivars used in transforming papaya were the Red fleshed, Sunset and the Yellow fleshed Kopoho. Transformation with the coat protein gene is done using a micro projectile bombardment technique using embryonic tissues of papaya. Two transgenic lines Sun UP from Sunset and UH Rainbow from Kapoho were developed which have shown excellent resistance to PRSV. Papaya ring spot virus (PRSV) reduces both fruit quality and edible yield. Transgenic papaya with a pathogen derived resistance carrying the coat-protein gene provides effective protection against PRSV strains over a significant period of the cycle of this perennial fruit crop.

\section{Banana}

Transgenic banana resistant to bunchy top disease
Symptoms Typical symptoms of BBTD include the appearance of dark green broken streaks of leaf veins, midribs, petioles and pseudostem with a group of clustered leaves on the top of the plant looks bunchy appearance (Borth et al., 2011). Reported BBTV resistant banana clone development through RNAi technology Agrobacteriummediated transformation of embryogenic banana cell suspensions with constructs that may prevent the replication of BBTV has been favoured by many research groups, as there is a much better chance of a plant developing that is not a chimera. In 2011, it was reported that some transformed clones of 'Dwarf Brazilian' (AAB, Pome subgroup) were resistant to BBTV under experimental conditions in Hawaii.

Shekhawat et al., (2012) have published an account of tests that showed that transformed 'Rasthali' (AAB genome, syn. 'Silk') did not develop symptoms when exposed to aphids carrying BBTV. They have explored the concept of using intron-hairpin-RNA (ihpRNA) transcripts corresponding to viral master replication initiation protein (Rep) to generate BBTV-resistant transgenic banana plants.

Elayabalan et al., (2013) reported on the Agrobacterium-mediated transformation on a highly valued hill banana cultivar Virupakshi (AAB) for resistance to BBTV disease. The target of the RNA interference (RNAi) is the rep gene, encoded by the BBTV-DNA1. The presence of the transgenes was conformed in the selected putative transgenic hill banana lines by PCR and reverse transcription PCR analyses. Transgenic hill banana plants expressing RNAi- BBTV-rep were obtained and shown to resist infection by BBTV. The transformed banana plants were symptomless, and the replication of challenge BBTV almost completely suppressed. 
Klopez (2012) reported that Banana Xanthomonas wilt (BXW), caused by the bacterium Xanthomonas campestris pv. musacearum $(\mathrm{Xcm})$, is the most devastating disease of banana in the Great Lakes region of Africa. IITA, in partnership with NARO-Uganda and the African Agricultural Technology Foundation, has developed transgenic banana by constitutively expressing the Hypersensitive Response Assisting Protein (Hrap) or plant ferredoxinlike protein $(P f l p)$ gene from sweet pepper (Capsicum annuum). The transgenic plants have exhibited strong resistance to $\mathrm{BXW}$ in the laboratory and screen house tests. The best 65 resistant lines were planted in a confined field trial at the National Agricultural Research Laboratories (NARL), Kawanda, Uganda, for further evaluation.

\section{Plum}

Plum is one of the tree fruits threatened by Plum pox poty virus (PPV) a quarantine disease that causes fruit loss to plums and other stone fruits.. As an enhancement to classical breeding, genetic engineering was used to produce transgenic clones that contain the PPV coat protein $(\mathrm{CP})$ gene, applying the principle of pathogen derived resistance. Gene for PPV virus coat protein insertedinto plant genome and result of this effort was the development of a transgenic clone designated as C5 (cv.Honey Sweet) Developed by Gene silencing or RNA interference (RNAi) at USDA-ARS Appalachian Fruit Research Station, which is resistant to Plum Pox Virus (PPV).

\section{Apple}

The "non browning" apple is genetically engineered to keep from going brown after being cut. When apple flesh is cut and exposed to oxygen, it begins to brown. But the genetically modified apple or "Arctic Apple," is resistant to browning. The "nonbrowning" genetically modified apples are designed to look fresh when they're not. It was developed by silencing a gene in the apple (that controls browning) by inserting modified apple DNA. It is approved for sale by USDA in 2015.

\section{Pineapple}

The "extra sweet pink flesh pineapples" are set to be launched by Del Monte. The fruit has been genetically engineered to produce fewer enzymes that are naturally responsible for converting lycopene to beta carotene. The suppression of enzymes will leave the flesh of the fruit pink, as the genes retain the pink pigment lycopene instead of beta carotene.

\section{Grapes}

Nirala et al., (2010) reported that to enhance the antifungal potential of grapevine, transgenic plants were generated by transferring a rice chitinase gene under a maize-ubiquitin promoter along with its first intron into the leaf disc-induced somatic embryos via Agrobacterium mediated transformation. After co-cultivation for 2 days with recombinant Agrobacterium, somatic embryos were transferred onto WPM medium containing BAP $1.5 \mu \mathrm{M}$ and NAA $0.1 \mu \mathrm{M}$ supplemented with $25 \mathrm{mg} /$ Lhygromycin. Secondary or tertiary embryos were selected and the antibiotic resistant transgenic plantlets were analyzed. The integration and stability of the transgene were confirmed by PCR, RTPCR, Southern blotting and by Western blot analyses. The transgenic plants exhibited higher chitinase activity than the nontransformed plants.

\section{Sweet orange}

Omar et al., (2008) stated that 'Hamlin' sweet orange (Citrus sinensis (L.) Osbeck) is one of the leading commercial cultivars in Florida 
because of its high yield potential and early maturity. 'Hamlin' also has a high regeneration capacity from protoplasts and is often used in transformation experiments. A Citrus canker disease caused by the bacterial pathogen Xanthomonas axonopodis pv.citriis becoming a worldwide problem in sweet orange. Plasmid DNA (pARS108) encoding the non-destructive selectable marker EGFP (Enhanced Green Fluorescent Protein) gene, and the plasmid cDNA of the Xa21 gene (pXa21-mtaq) were co-transformed into 'Hamlin' orange protoplasts using polyethylene glycol. More than 150 transgenic embryoids were recovered. Over a thousand transgenic plantlets GFP positive were regenerated from 150 independent transformation events. PCR analysis revealed the presence of the cDNA of the Xa21 and the GFP genes in some of the transgenic plantlets. The recovery of transgenic plants was expedited by in vitro grafting. The transgenic plants have shown normal growth and stable GFP expression for over a year in the greenhouse. Southern blot analysis is showing $0-5$ copies of the transgene per transgenic plant.

\section{Grape fruit}

Febres et al., (2008) reported that grapefruit (Citrus paradisi) transgenic plants transformed with a variety of constructs derived from the Citrus tristeza virus (CTV) genome were tested for their resistance to the virus. Most transgenic lines were susceptible (27 lines), a few were partially resistant (6 lines) and only one line, transformed with the 3 ' end of CTV was resistant.

\section{Guava}

Mishra et al., (2014) reported that guava wilt disease is a severe threat to guava growers all over the world. It is caused by the soil-borne fungus Fusarium oxysporum f.sp. psidii. To control the disease, the Trichodermaendochitinase gene was first introgressed into guava (Psidium guajava L.). The transgenic plantlets were screened in vitro for resistance against the wilt pathogen. Six-months-old genetically transformed plants raised in cocopeat under in vitro conditions were inoculated with a 7-days old culture of $F$. oxysporumf.sp. psidii. The presence of the pathogen in the cocopeat medium was confirmed by cultural as well as PCR analysis using species-specific primers. The roots of transgenic plants were wounded to facilitate the entry of the pathogen. The histopathological analysis revealed the presence of mycelium in vascular bundles. However, none of the plants showed symptoms of wilt disease during the investigation. Transgenic plants could not develop any symptoms of wilt disease due to overexpression of endochitinase.

\section{Kiwi}

The kiwifruit (Actinidia chinensis Planch.) is an economically and nutritionally important fruit crop that has remarkably high vitamin $\mathrm{C}$ content and is popular throughout the world. However, kiwifruit plants are vulnerable to attack from pests, and effective pest control is urgently required. Zhang et al., (2015) reported that transgenic kiwifruit plants containing the synthetic chimeric gene SbtCry1Ac that encodes the insecticidal protein btCrylAc were obtained through an Agrobacterium-mediated transformation of kiwifruit leaf discs. The kanamycin resistance of the transgenic plants was then analyzed. Results of polymerase chain reactions and genomic DNA Southern blot analyses indicated that SbtCrylAc had been integrated into the genomes of these plants. The results of insect bioassays revealed that the average Oraesia excavate inhibition rate of plants tested at 10 days post-infestation was $75.2 \%$. 


\begin{tabular}{|c|c|c|c|c|c|}
\hline \multicolumn{6}{|c|}{ Table.1 } \\
\hline ]Crop & Character & Gene transferred & $\begin{array}{l}\text { Method of gene } \\
\text { transfer }\end{array}$ & Variety & Reference \\
\hline $\begin{array}{l}\text { Transgenic } \\
\text { papaya }\end{array}$ & PSRV Resistant & $\begin{array}{l}\text { coat protein gene } \\
\text { from PRSV }\end{array}$ & $\begin{array}{l}\text { micro projectile } \\
\text { bombardment } \\
\text { technique }\end{array}$ & $\begin{array}{l}\text { Sun UP from } \\
\text { Sunset and UH } \\
\text { Rainbow from } \\
\text { Kapoho }\end{array}$ & $\begin{array}{l}\text { Gonsalves } \\
(1992)\end{array}$ \\
\hline $\begin{array}{l}\text { Transgenic } \\
\text { banana }\end{array}$ & $\begin{array}{l}\text { Banana Bunchy } \\
\text { top Virus }\end{array}$ & $\begin{array}{l}\text { Replicase- associated } \\
\text { gene (Rep gene) }\end{array}$ & $\begin{array}{l}\text { RNAi } \\
\text { technology } \\
\text { Agrobacterium- } \\
\text { mediated } \\
\text { transformation }\end{array}$ & $\begin{array}{l}\text { Dwarf } \\
\text { Brazilian } \\
\text { (AAB) Pome } \\
\text { sub group }\end{array}$ & $\begin{array}{l}\text { Borth et al., } \\
\text { (2011) }\end{array}$ \\
\hline $\begin{array}{l}\text { Transgenic } \\
\text { banana }\end{array}$ & $\begin{array}{l}\text { Banana Bunchy } \\
\text { top Virus }\end{array}$ & $\begin{array}{lr}\text { master } & \text { replication } \\
\text { initiation } & \text { protein } \\
(\text { Rep) } & \end{array}$ & $\begin{array}{l}\text { Agrobacterium- } \\
\text { mediated } \\
\text { transformation }\end{array}$ & $\begin{array}{l}\text { Rasthali' (AAB } \\
\text { genome) }\end{array}$ & $\begin{array}{l}\text { Shekhawat et } \\
\text { al., (2012) }\end{array}$ \\
\hline $\begin{array}{l}\text { Transgenic } \\
\text { banana }\end{array}$ & $\begin{array}{l}\text { Banana Bunchy } \\
\text { top Virus }\end{array}$ & $\begin{array}{l}\text { Replicase- associated } \\
\text { gene (Rep gene) } \\
\text { RGA2 gene from } \\
\text { banana and Ced9 } \\
\text { gene, is derived from } \\
\text { a nematode }\end{array}$ & $\begin{array}{l}\text { Agrobacterium- } \\
\text { mediated } \\
\text { transformation }\end{array}$ & $\begin{array}{l}\text { Virupakshi } \\
\text { (AAB) }\end{array}$ & $\begin{array}{l}\text { Elayabalan et } \\
\text { al., (2013) }\end{array}$ \\
\hline $\begin{array}{l}\text { Transgenic } \\
\text { banana }\end{array}$ & Xanthomonas wilt & $\begin{array}{l}\text { Plant ferredoxin-like } \\
\text { protein (Pflp) gene } \\
\text { from sweet pepper } \\
\text { (Capsicum annuum). }\end{array}$ & $\begin{array}{l}\text { Agrobacterium- } \\
\text { mediated } \\
\text { transformation }\end{array}$ & $\begin{array}{l}\text { 'SukaliNdiizi', } \\
\text { and } \\
\text { 'Nakinyika', }\end{array}$ & $\begin{array}{l}\text { Klopez } \\
(2012)\end{array}$ \\
\hline $\begin{array}{l}\text { Transgenic } \\
\text { Pear }\end{array}$ & $\begin{array}{l}\text { Fire blight } \\
\text { (Erwinia } \\
\text { amylovora) } \\
\text { produces } \\
\text { (desferrioxamine } \\
\text { protein }\end{array}$ & $\begin{array}{l}\text { Exogenous ferritin } \\
\text { gene which acts as } \\
\text { iron chelator from pea }\end{array}$ & $\begin{array}{l}\text { Agrobacterium- } \\
\text { mediated } \\
\text { transformation }\end{array}$ & $\begin{array}{l}\text { 'Conference' } \\
\text { and 'Passe- } \\
\text { Crassane' }\end{array}$ & $\begin{array}{l}\text { Djennane et } \\
\text { al., (2009) }\end{array}$ \\
\hline $\begin{array}{l}\text { Grapefruit } \\
\text { (Citrus } \\
\text { paradisi) } \\
\end{array}$ & citrus tristeza & closterovirus genes & $\begin{array}{l}\text { Agrobacterium- } \\
\text { mediated } \\
\text { transformation }\end{array}$ & - & $\begin{array}{l}\text { Febres et al., } \\
(2008)\end{array}$ \\
\hline $\begin{array}{l}\text { Guava } \\
\text { (Psidium } \\
\text { guajava) } \\
\end{array}$ & guava wilt & $\begin{array}{l}\text { Trichoderma- } \\
\text { endochitinase gene }\end{array}$ & $\begin{array}{l}\text { Agrobacterium- } \\
\text { mediated } \\
\text { transformation }\end{array}$ & - & $\begin{array}{l}\text { Mishra et al., } \\
\text { (2014) }\end{array}$ \\
\hline $\begin{array}{l}\text { Guava } \\
\text { (Psidium } \\
\text { guajava) } \\
\end{array}$ & $\begin{array}{l}\text { cold } \\
\text { temperaturestolere } \\
\text { nce }\end{array}$ & $\begin{array}{l}\text { cold hardiness genes } \\
\text { (CBF1, CBF2 and } \\
\text { CBF3) }\end{array}$ & $\begin{array}{l}\text { Agrobacterium- } \\
\text { mediated } \\
\text { transformation }\end{array}$ & - & $\begin{array}{l}\text { Biswas et al., } \\
(2005)\end{array}$ \\
\hline Kiwifruit & $\begin{array}{l}\text { Resistance to the } \\
\text { insect Oraesia } \\
\text { excavate }\end{array}$ & $\begin{array}{l}\text { synthetic chimeric } \\
\text { gene SbtCry1Ac that } \\
\text { encodes the } \\
\text { insecticidal protein } \\
\text { btCrylAc }\end{array}$ & $\begin{array}{l}\text { Agrobacterium- } \\
\text { mediated } \\
\text { transformation }\end{array}$ & - & $\begin{array}{l}\text { Zhang et al., } \\
\text { (2015) }\end{array}$ \\
\hline $\begin{array}{l}\text { Trifoliate } \\
\text { orange }\end{array}$ & salinity tolerance & $\begin{array}{l}\text { Betaine aldehyde } \\
\text { dehydrogenasegene } \\
(A h B A D H) \quad \text { gene }\end{array}$ & $\begin{array}{l}\text { Agrobacterium- } \\
\text { mediated } \\
\text { transformation }\end{array}$ & - & $\begin{array}{l}\mathrm{Fu} \text { et al., } \\
(2011)\end{array}$ \\
\hline
\end{tabular}




\begin{tabular}{|c|c|c|c|c|c|}
\hline & & $\begin{array}{l}\text { cloned from Atriplex } \\
\text { hortensis } \\
\text { (Mountain spinach }\end{array}$ & & & \\
\hline $\begin{array}{l}\text { American } \\
\text { cranberry } \\
\text { (Vaccinium } \\
\text { macrocarpon } \\
\text { Ait.) } \\
\end{array}$ & $\begin{array}{l}\text { conferring } \\
\text { tolerance to the } \\
\text { phosphinothricin- } \\
\text { based herbicide } \\
\text { glufosinate }\end{array}$ & bar gene & $\begin{array}{l}\text { Agrobacterium- } \\
\text { mediated } \\
\text { transformation }\end{array}$ & - & $\begin{array}{l}\text { Zeldin et al., } \\
(2002)\end{array}$ \\
\hline $\begin{array}{l}\text { Vitis vinifera } \\
\text { (V.berlandieri } \\
x \quad V . \text { riparia) } \\
\text { and } \\
\text { 41B (V.v } x \quad V . \\
\text { berl.) }\end{array}$ & Virus resistance & $\begin{array}{l}\text { LBA } 4404 \text { GFLV cp } \\
\text { gene }\end{array}$ & $\begin{array}{l}\text { Anther-derived } \\
\text { embryogenic } \\
\text { callus }\end{array}$ & - & $\begin{array}{l}\text { Mauro et al., } \\
(1995 ., 2000)\end{array}$ \\
\hline V. rupestris & Virus resistance & $\mathrm{CP}$ of ArMV & $\begin{array}{l}\text { Somatic } \\
\text { embryos }\end{array}$ & - & $\begin{array}{l}\text { Spielmann et } \\
\text { al., (2000) }\end{array}$ \\
\hline V. vinifera & Fungal resistance & $\begin{array}{l}\text { Rice } \\
\text { (RCC2) }\end{array}$ & $\begin{array}{l}\text { Somatic } \\
\text { embryos }\end{array}$ & 'NeoMuscat' & $\begin{array}{l}\text { Yamamoto et } \\
\text { al., (2000) }\end{array}$ \\
\hline V. vinifera & Cold resistance & $\begin{array}{ll}\text { SOD } & \text { from } \\
\text { Arabidopsis } & \end{array}$ & A. tumefaciens & $\begin{array}{l}\text { 'Cabernet } \\
\text { Franc' }\end{array}$ & $\begin{array}{l}\text { Rojas et al., } \\
(1996)\end{array}$ \\
\hline V. vinifera' & $\begin{array}{l}\text { Modified fruit } \\
\text { traits }\end{array}$ & DefH9/iaaM & A. tumefaciens & $\begin{array}{l}\text { Silcora', } \\
\text { 'Thompson } \\
\text { Seedless' }\end{array}$ & $\begin{array}{l}\text { Mezzetti et } \\
\text { al., (2002) }\end{array}$ \\
\hline Vitis vinifera & $\begin{array}{l}\text { Modified fruit } \\
\text { traits }\end{array}$ & $\begin{array}{l}\text { UDP:flavonoid 3-O- } \\
\text { glucosyltransferase } \\
\text { (UFGT }\end{array}$ & A. tumefaciens & & $\begin{array}{l}\text { Thomas et } \\
\text { al., (2001) }\end{array}$ \\
\hline
\end{tabular}

\section{American craneberry}

Zeldin et al., (2002) reported that American cranberry (Vaccinium macrocarpon Ait.) was genetically transformed with the bar gene, conferring tolerance to the phosphinothricinbased herbicide glufosinate.

\section{Trifoliate orange}

Trifoliate orange (Poncirus trifoliata L. Raf.), a rootstock widely used for citrus species, is salt-sensitive. Worldwide, salinity is a major abiotic stress affecting citrus growth and yield. Fu et al., (2011) reported that a betaine aldehyde dehydrogenase gene $(A h B A D H)$ cloned from Atriplexhortensis was introduced into the trifoliate orange by means of Agrobacterium-mediated transformation. RT-PCR analysis on three selected transgenic lines showed that the $A h B A D H$ gene was overexpressed in each of them. GB levels in these lines were also higher than those in untransformed wild-type (WT) plants. His data suggest that overexpression of the $A h B A D H$ gene in transgenic trifoliate orange enhanced salt stress tolerance.

It is concluded as genetically-modified fruit crops in addition to food grain crops have the potential to solve many of the world's hunger and malnutrition problems. However, transgenic research in fruit crops is very low due to difficulty in regeneration and 
transformation procedure being perennial and woody in nature. The long term effects of GMOs are not certain. Most of the fruit genetic transformation protocols integrated the new genes randomly and in unpredictable copy numbers influencing negatively its expression. Public concerns and reduced market acceptance of transgenic crops have promoted the development of alternative marker free technologies in fruit species. Most of the fruit transgenic plants are generated by introducing just one single new character (gene of interest), however, multigene transfer technology (MGT) needs to be developed to obtain new traits related at the same time.

\section{References}

Borth, W., Perez, K., Cheah, Y., Chen, W. S., Xie, D., Gaskill, S., Khalil, D., Sether, M., Melzer, M., Wang, R., Manshardt, D., Gonsalves and $\mathrm{Hu}$, J.S.2011. Transgenic banana plants resistant to banana bunchy top virus infection. Acta Hort. 897:449-457

Djennane, S, Cesbron, C, Sourice, Sophie and Loridon K and Chevreau, E.2009. Production of transgenic pear plants expressing ferritin gene with aim to reduce fire blight susceptibility. Acta Horticulturae. 814:781-786

Elayabalan, S. K., Kalaiponmani, S., Sreeramanan, R., Selvarajan, P., Radha, M., Ramlatha, K., Kumar, K and Balasubramanian, P. 2013. Development of Agrobacteriummediated transformation of highly valued hill banana cultivar Virupakshi (AAB) for resistance to BBTV disease. World J. Microb. Biotech. 29:589-596

Febres, V.J., Lee, R.F and Moore, G.A. 2008. Transgenic resistance to Citrus tristeza virus in grapefruit. Plant Cell Reports.27: 93-104.
Fu, X., Khan, E.U, Hu, S.S., Fan, Q.J., Liu, J.H. 2011. Overexpression of the betaine aldehyde dehydrogenase gene from Atriplex hortensis enhances salt tolerance in the transgenic trifoliate orange (Poncirus trifoliate L. Raf). Environmental and Experimental Botany 74: 106-113

Gonsalves C, Tennant P, Fermin G, Souza M. 1992. A protocol for efficient transformation and regeneration of Carica papaya L, In Vitro Cellular and Developmental Biology. Plant 35: 61-69.

Khandelwal, Kuruganti, K. and Ramanjaneyulu, G.V. 2011. Genetic Engineering in Indian Agriculture An Introductory Handbook: Pp.2-5.

Klopez. 2012. Transgenics in crop improvement research, IITA, accessed fromhttp://r4dreview.iita.org/index.ph p/2011/04/14/transgenic-banana-forafrica/ on 25-9-2018.

Mauro, M.C., Toutain, S., Walter, B., Pinck, L., Otten, L., Coutos-Thevenot, P., Deloire, A., Barbier, P. 1995. High efficiency regeneration of grapevine plants transformed with the GFLV coat protein gene. 112,:97- 106

Mezzetti, B., Pandolfini, T., Navacchi, O., Landi, L. 2002. Genetic transformation of Vitis vinifera via organogenesis. BMC Biotechnology. 2:18

Mishra, M., Jalil, S.U., Sharma, N., Hudedaman, I U. 2014. An Agrobacterium mediated transformation system of guava (Psidium guajava L.) with endochitinase gene. Crop Breeding and Applied Biotechnology. 14: 232237.

Nirala, N. K., Das, D.K.., Srivastava, P.S., Sopory, S.K. and Upadhyaya, K.C. 2010. Expression of a rice chitinase gene enhances antifungal potential in 
transgenic grapevine (Vitis vinifera L.). Vitis, 49 (4): 181-187

Omar, A.A. and Grosser, J.W. 2007. Protoplast Co-Transformation and Regeneration of Transgenic 'Hamlin' Sweet Orange Plants Containing a cDNA Xa21 Xanthomonas Resistance Gene and Proc. Acta Horticulturae. 738: 235-243

Rojas,B., McKersie, B.D, Paroschy, J.H. 1996. Agrobacterium-mediated transformation of Vitis vinifera. 4th Canadian Plant Tissue Culture and Genetic Engineering Workshop, Saskatoon, http://www.plant.uoguelph.ca/research / embryo/abstract.htm

Shekhawat, U. K. S., R. Thumballi, T. R. Ganapathi and A. B. Hadapad. 2012. Transgenic banana plants expressing small interfering RNAs targeted against viral replication initiation gene display high-level resistance to banana bunchy top virus infection. J. Gen. Virol. 93:1804-1813

Spielmann, A., Krastanova S, Douet-Orhant V, Gugerli, P. 2000. Analysis of transgenic grapevine (Vitisrupestris) and Nicotiana benthamiana plants expressing an Arabis mosaic virus coat protein gene. Plant Science 156, 235-244

Thomas M, Scott N. 2001. PR-142: Evaluation of transgenes in grapevine No. 2. Available online: http://www.ogtr.gov. au/pdf/volsys/pr142.pdf

Yamamoto, T., Iketani, H., Ieki, H., Nishizawa, Y., Notsuka, K., Hibi T., Hayashi, T., Matsuta, N. 2000. Transgenic grapevine plants expressing a rice chitinase with enhanced resistance to fungal pathogens. Plant Cell Reports 19:639646

Zeldin E, Jury TP, Serres RA, McCown BH.2002. Tolerance to the herbicide glufosinate in transgenic cranberry (Vaccinium macrocarpon Ait.) and enhancement of tolerance in progeny. Journal of American Society for Horticultural Science 127: 502-507.

Zhang, H.Y., Liu, H.M. and Liu, X.Z.2015. Production of transgenic kiwifruit plants harboring the SbtCry1Ac gene Genet. Mol. Res. 14 (3): 8483-8489

\section{How to cite this article:}

Prasanna, V.S.S.V., E.K. Naik, Siva Sankar Reddy, K. 2018. Transgenics in Fruit Crops Research- A Review. Int.J.Curr.Microbiol.App.Sci. 7(12): 3000-3007. doi: https://doi.org/10.20546/ijcmas.2018.712.344 